\title{
Problems of the organization of surface and underground space (e.g. historical embankments of Saint Petersburg)
}

\author{
S.L. Shapiro, M.P.Kopkov, I.V. Potseshkovskaya \\ Saint-Petersburg Mining University, Department of Architecture, Faculties Civil Engineering, St \\ Petersburg, Russia
}

\begin{abstract}
The article explores modern approaches to urban environment improvement, reconstruction ofSt. Petersburg embankments in the historic center, management of the pedestrian environment and public spaces. The concept of creating multifunctional underground and subaqueous thruways close to the historical development of St. Petersburg has maximum potential. The article gives several of embankment spaces from domestic and foreign experience and analyzes some transport problems. The projects of different years are studied. A new urban planning concept for the solving problem of separation of traffic and pedestrian traffic, aimed at the development of public space near water is proposed
\end{abstract}

\section{Introduction}

One of the modern trends in the transformation of urban space in historic cities is the creation of a pedestrian environment along waterways. The problem of reforming the transport system in the historic city center with the riverfront seems to be one of the most important. In general, traffic arteries that are part of the transportation system cross the waterfront [1]. As Vukan R. Vuchic marked: "Transport forms the cities and affects their livability... Many elements, which determine the convenience of particular territory for living, depend on the type and quality of its transport system directly or indirectly" [2, 27].

In the modern transportation system of St. Petersburg, the Neva embankments are the most important water transport arteries of urban waterway transport with heavy traffic. On many embankments in the historic center of the city, pedestrians are provided with only a narrow sidewalk. Vehicles typically move along the embankments in multiple rows and at high speeds. In fact, there are very few pedestrian crosswalks. Pedestrians are cut off from the water by car traffic $[3,14]$. As stated in the Retrospective Declaration of Outstanding Universal Value of the World Heritage Site, "Historic Center of St. Petersburg and Related Groups of Monuments", "the full-flowing Neva has given the city an exceptional spatial scope and spectacular richness, and has become the main square and main Avenue of St. Petersburg" [4]. However, at present it is difficult to verify this. In the area of the Palace embankment, pedestrian crosswalks are located at a distance of 230-300 meters, some areas don't have crosswalks for 540 meters. Access to the embankments is provided by public 
transport, sightseeing buses and partly by subway. At the same time, disembarkation from public transport is difficult for low-mobile groups of population, and the central embankments are poorly adapted for their recreation [20]. It is important to understand that it is impossible to leave the historical center of St. Petersburg exclusively for tourism. It is necessary to modify public spaces to attract citizens and ensure a comfortable stay on the embankment.

\section{Researches}

In olden days, the main transport artery of the city was the Neva River and its adjacent rivers and canals. They delivered both passengers and all the necessary goods to the citizens. Before the advent of bridges, communication with some parts of the city was done solely by water. In recent decades, subaqueous and surface transport highways appeared, allowing citizens not to be deprived of accessibility during the navigation and lifting of bridges.

The city's historic embankments and the waters of the Neva River are not only a promenade area but an area zone of cultural events: during the warm season there are cycling and marathon races, many water sports performances. During such city events, traffic stops along the embankments and adjacent streets (Fig. 1).
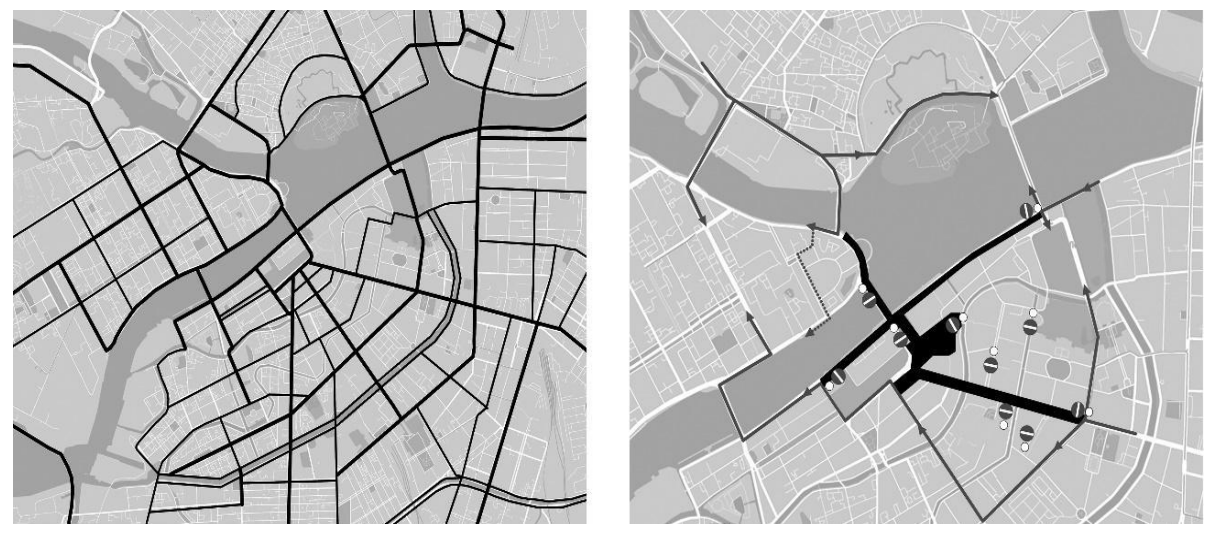

Fig. 1. The main scheme of traffic in the center part of St. Petersburg (left). Scheme of the prohibition of traffic during cultural events in the evening (right).

Such temporary events are designed for several hours. The complete elimination of traffic on the central city embankments is not possible in the near future.

The main objective of creating a pedestrian zone along the banks of the Neva Riverin the historic center of Saint Petersburg is to eliminate the conflict between traffic and pedestrian flows (Fig. 2). 


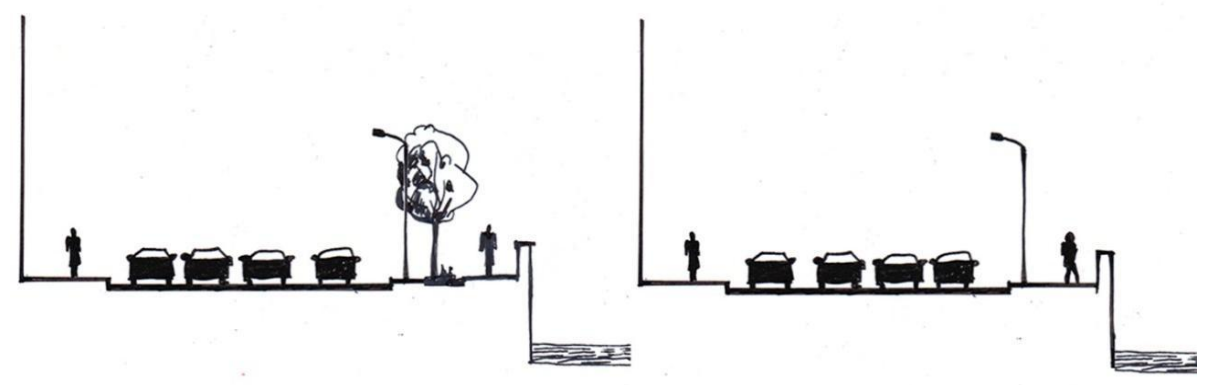

Fig. 2.Types of schematic sections of existing embankments with historical buildings in Saint Petersburg.

The use of underground and subaqueous space could help solve this problem. It seems most convenient to use the following scheme for stream separation: people stay above; transport goes underground or underwater. The advent of new technologies for performing underground and underwater works required the creation of project proposals that could combine the efforts of specialists from different areas of expertise [17, 21].

The development of embankments in the historic center of Saint Petersburg includes objects of history and culture- architectural monuments. The very structure of the base of the embankment should also be protected (Fig. 3) [15].

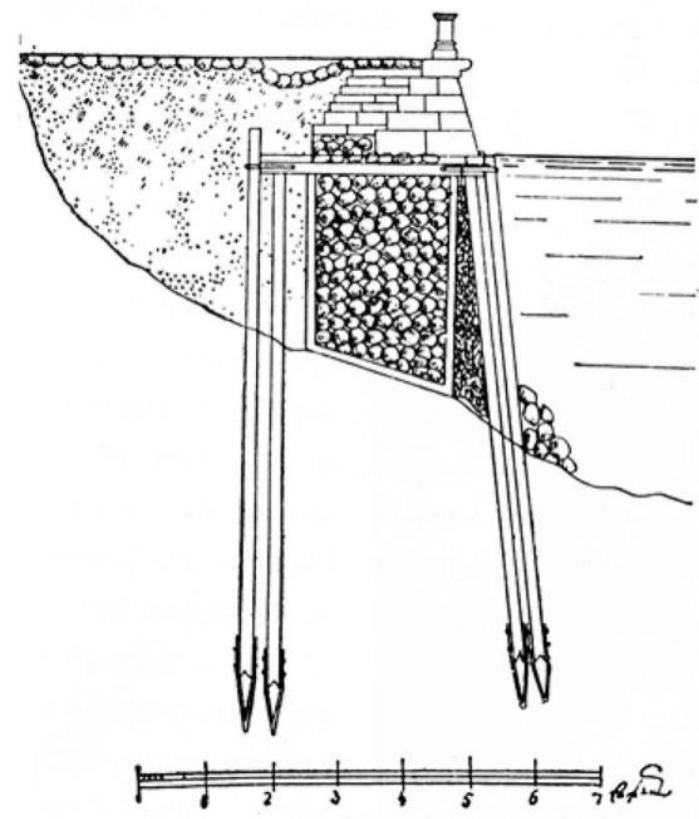

Fig. 3. The project of granite embankment near the Winter Palace. Section drawing(Unknown artist1758).

Under Peter I, naval buildings along St. Petersburg's embankments had bypass canals ( e.g. the Admiralty building). The filling of the outer Admiralty canal in 1814-1819, the destruction of the docks, and the inner canal during the construction of the embankment 
significantly changed the surrounding area (Fig.4). The garden was planted here and apartment buildings were built on the embankment.

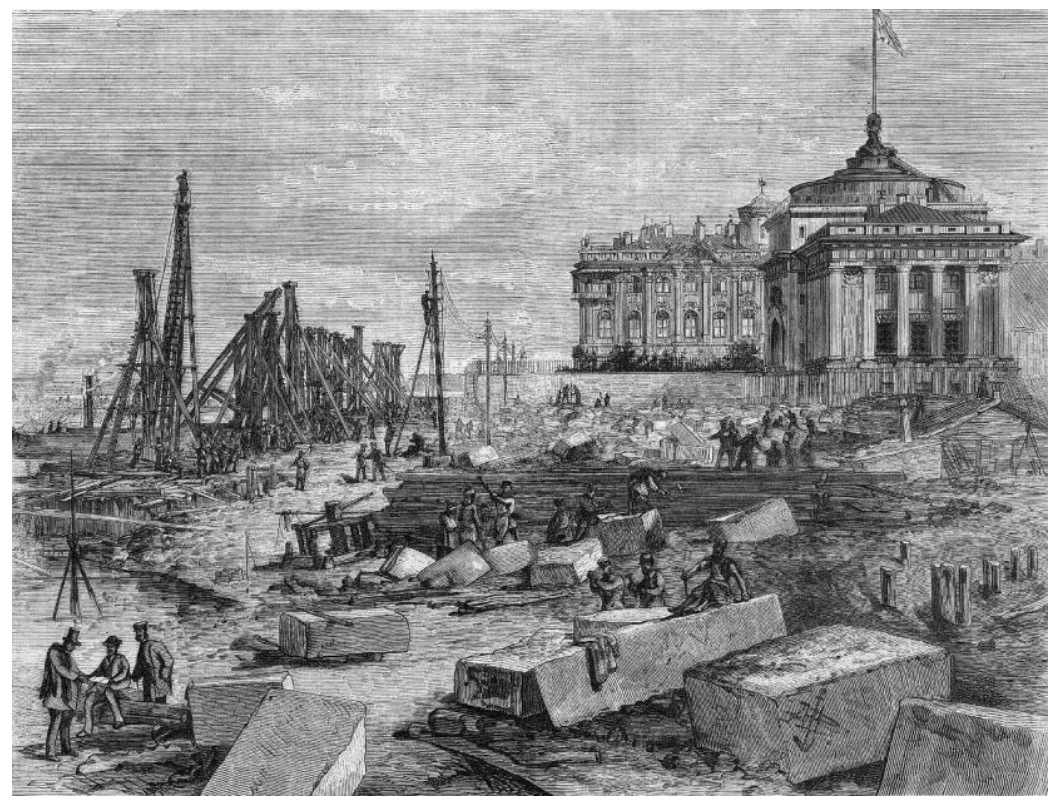

Fig. 4. Engraving. Construction of the Admiralty embankment (Beggrov, engraved Kammuller 1873).

Over time, the requirements for urban water areas have changed.

The transformation of the city's primary operational function from a naval harbor of the Russian Empire on the northwestern borders to an administrative and commercial seaport have favored the spatial planning of land crossings and the construction of bridges. With the development of science and technology in the 19th century, innovative engineering solutions began to appear in the urban landscape of St. Petersburg.

There is documented, though unproven information about the first drawings of tunnels not implemented in St. Petersburg, which were drawn in the early 19th century. It is said that in 1814 Alexander I granted an audience to an English engineer of French descent, Marc Brunel, who presented the Russian Emperor with a"revolutionary" drawings of the tunnel under the Neva River [22]. Mark Brunel later patented the tunnel shield in Great Britain and supervised the construction of the tunnel under the Thames in 1842 [2]. During its construction, the tunnel became an architectural and engineering landmark and later the oldest section of the London Underground. It became an example of a successful adaptation of the current type of structures. Most often, the historical prospects for transport structures that lose their original significance are destruction.

There are several examples of successful use of modern technologies for work in complex hydrogeological conditions, made in the existing architectural world [23]. These technologies have been used since the 1970s. For one thing, when using the "method of lowering sections", structures are lowered to the bottom, and then water is pumped out of them. This technology was used in the construction of large tunnels in Belgium, Italy, Germany, and Great Britain. The described method was also used to construct the KanonerskyTunnel in Saint Petersburg in 1975 - 1983. It is located in the KirovskyDistrict of St. Petersburg under the Sea Canaland connects Gutuevsky (Dvinskaya street) and Kanonersky Islands.

It was noted, that the implemented drawings of automobile and pedestrian tunnels in St. Petersburg in the vicinity of the embankments were built by open-cut method. This was the 
way were built, the Left Bank Transport Tunnel was built in 1968-1969 under the Liteyny Bridge, and the SinopskyRoad Tunnel, completed in 2017. The CruisePassageshould be also considered as it was built on the grounds of the largest museum complex, the Hermitage, in 2016. Also, Cruise Passageis a service underground passage between the Small and the $\mathrm{Big}(\mathrm{Old})$ Hermitage; its length is 8 meters, 1 width - 4.6 meters.Most importantly, the tunnel is located not only in the area of protection of the architectural monument, but also on the site of archaeological excavations.

The Historic Center of St. Petersburg and Related Groups of Monuments are considered to be the first UNESCO world heritage site in the Russian Federation (and the former USSR). Currently, all new constructions in the historic center of St. Petersburg are strictly prohibited by state law. It is conducive to preserve the integrity of the ensemble development of the central blocks and the river facade of the city, which opens to the Neva River and forms a panoramic perception of the urban landscape from the water artery (May 2019.). At the same time, previously created blueprints for moving vehicle transport into tunnels along historical embankments remain unimplemented.

For example, the Orlovsk tunnel was envisaged as part of a large-scale infrastructure project to bypass the center (TOC) implemented in St. Petersburg. The tunnel design was developed to significantly reduce the flow of road transport passing through the historical center. In addition, the drawings of the Kronverk transport corridor, the Nevsky automobile tunnel, and the Nevsky Prospect development scheme were also reviewed(Fig. 5). The main disadvantage of these projects is the violation of the historical appearance of the embankments.

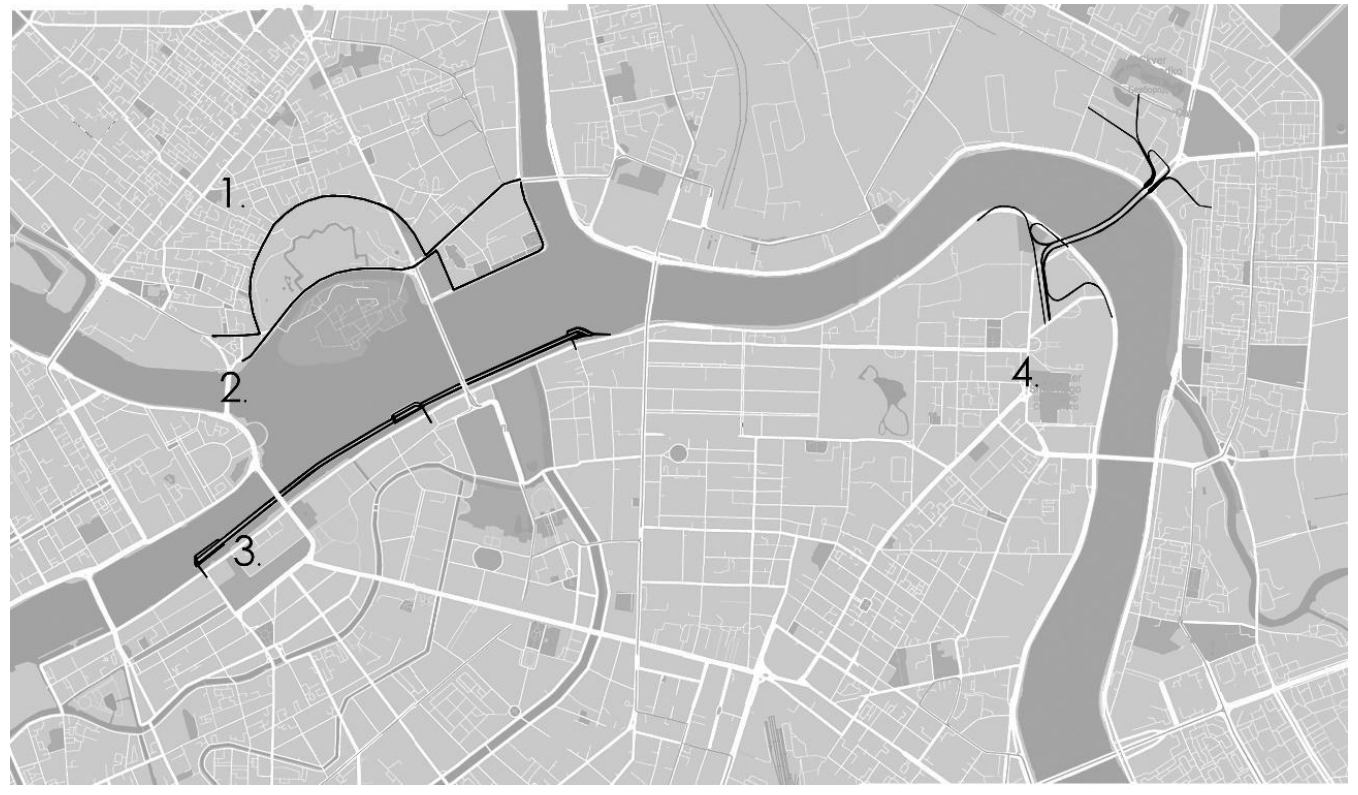

Fig. 5. Schemes of the Kronverk transport corridor $(1,2)$, the route of the Nevsky automobile tunnel (3), and the Orlovsky tunnel (4).

There are several modern examples of the construction of tunnels under embankments in the world. This way, the issue of clearing embankments for promenade routes along the waterway in central quarters of cities was solved. The main difference from this issue is the absence of existing historic buildings and embankment structures of historical value. The Spanish Madrid-Rioprojectis one of the best examples of how places not adapted for a public function became important points of attraction for people after revitalization. It 
became possible not only to provide underground parking and organize places for walks, but also to transform this area into a real garden with fruit trees and fountains, enriching the urban environment with a new public space after the experience of using green spaces in the improvement of urban areas.

The second example is the road tunnel (German Rheinufertunnel) on the right bank of the Rhine in the central part of Dusseldorf. The tunnel is located in an area of historic development and is almost 2 kilometers long. It was restored in the post-war period in the 1940s and re-opened in 1993. The space, which is currently not used for automobile traffic, became a sign to allow for the new design of the Rhine embankment, which will be drawn to establish a pedestrian zone along the Rhine.

The large-scale Amfora project implemented in Amsterdam is considered as best example of organizing new public spaces along the surface and underground parts of historic embankments in modern foreign experience. In this project, highways and parking zones are built under the water canals as shown below (Fig. 6).
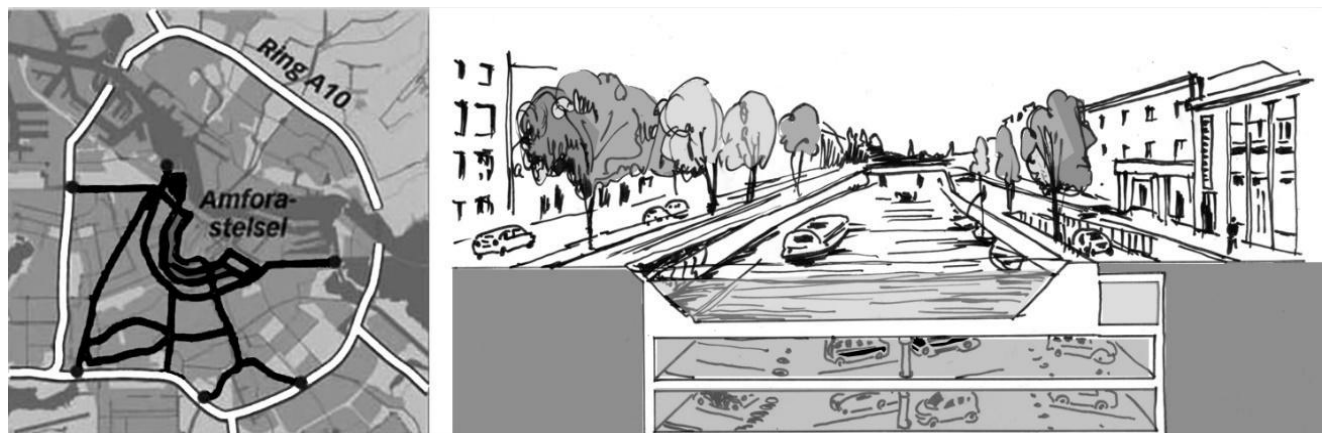

Fig. 6. Diagram of the Amfora Project (left). The layout of the parking space under the canal in the Amphora Project(Internet source 2019).

The complex provides not only parking areas but sports facilities and cinemas located on several underground levels. The authors of Amfora are the Strukton Engineering office, the Zwarts\&Jansma architectural workshop and the Delft University of Technology; they all use an original construction technique: they temporarily pump out of the city's water canals, then dig pits and start building tunnels that are not washed out with water, then the"holes"are"sealed" and the canals are refilled with water. This solution allows keeping the historic embankments and surrounding buildings intact. The first stage of the Amforahas already been completed. Funding issues in this project are resolved as cofinancing in the field of public and private capital.

During the reconstruction of embankments and the organization of traffic in the underground, the issue of placing bulky ramps for entering and exiting cars at historical buildings has become more relevant [4]. As an example, a river tunnel was opened in 1911 in Hamburg for the passage of cars, empty trucks, horse-drawn carriages, and carts, as well as cyclists and pedestrians. A Unique feature of the tunnel is the absence of an access road, and an elevator was built to take the people up and down from both sides of the river. Each of the tunnel entrances was equipped with four freightand two passenger elevators, which have been operating for more than 90 years without replacement.

For the sustainable development of St. Petersburg, it is necessary to humanize the city's waterfront, including the embankments in the central part of the city despite the many difficulties associated with it [16].

Following the United Nations' requirements for settlements and urban development, it is noted that "cities are not abstract machines that provide sustainability; people live, work, learn and fulfill themselves there [27]. Cities are creations of people; they are made by 
people and for people. Cities That strive to create a more livable and sustainable environment are considered to be a combination of housing, urban and social infrastructure"[14].

The bounds of the "Historical Center of St. Petersburg and Related Groups of Monuments" have been clarified by the UNESCO decision 37 COM 8B. 54, adopted at the 37 th session $[10,11]$. According to the data obtained in the information system of St. Petersburg, historical embankments acquired protected status by a UNESCO decision [24]. Not only the surrounding buildings and structures are protected, but also the historic hydraulic systems, including the watercourses of the Neva delta, the winter canal, and open water areas within the riverfront. At present the embankments are under the jurisdiction of the city and regional regulation, therefore the objects shall be granted a special townplanning status for the introduced elements for future development. The construction of tunnels in the Neva affects the water legislation. It should be taken into account that every year fish go down the Neva to spawn.

The difficulties in the process of considering options for the reconstruction of the historic embankments of St. Petersburg are properly accounted for, so the implementation of project proposals could be possible only if the existing regulatory norms are changed. It is necessary to work out the possibility of additional underground and aboveground areas to combine the functions of the museum areas with shopping, storage, and transport to make changes possible to the regulatory framework. The museum area of embankments could be multi-functional, it is one of the important factors when additional funding is needed due to the high cost of construction works.

\section{Conclusions}

New constructions are prohibited within the existing borders of the historical center of Saint Petersburg. However, the area that has only predominantly museum function is not capable of harmonious development and does not fully cope with the issue of filling new public functions in urban spaces and creating a comfortable environment(Podhalański2014), (Gelfond2020). In the context of the current ensemble development of the historical center of St. Petersburg, the development of the city's underground space has the main potential for the preservation of the architectural heritage and a "genius loci"("protective spirit of the place"). At this moment, the Russian Federation is developing a new regulatory framework for underground construction, which creates prerequisites for a comprehensive approach to addressing issues of reconstruction and of historical centers of developed cities $[5,6]$.

It is important to create not only design projects for underground tunnels and spaces, but also to work out a concept for the reconstruction of historical embankments, central squares, and streets with historic buildings, e.g. architectural monuments, using the underground space of the city. Freeing up land space with access to public functions inwater front, removing traffic flows in the central part underground, and organizing new public spaces and pedestrian routes in the riverfront would increase the potential for the development of the historic city.

Currently, there is no experience in the construction of tunnels in Saint Petersburg that would allow creating a comfortable and favorable environment for the urban population in the city center.

The multifaceted studies of historic cities, including in the framework of systemic and environmental approaches, have led to understanding the need to move from protective zoning (location around monuments, differentiation of these zones by value, and the use of universal regimes of their maintenance) to allocation of holistic in its characteristics districts, architectural ensembles, which allows to take into account the local specifics of the historical setting [1]. 
Routinely, large-scale riverfront reconstruction projects are implemented at the initiative or with the participation of city authorities, which provide a unified development strategy, project management with the need to establish special urban planning requirements, as well as investment incentives by providing incentives and preferences to developers. In order to solve this problem, the initiative of the population and city authorities to adapt the regulatory framework and encourage investment is necessary. And if this is done, the result will be as follows: the task of organizing new public spaces, focused on meeting the needs of citizens in a comfortable environment, as well as the needs of ecotourism along the historic embankments, will be able to find a real implementation.

\section{References}

1. S.A. Ageev, Auto abstract. Preservation of local historical complexes by methods of urban planning regulation. Chapter 1. Internet source. Available at: (https://archi.ru/files/publications/abstracts/ageev. htm) (2005).

2. H. Bagust, The Greater Genius A biography of Marc Isambard Brunel. Hersham: Ian Allan Publishing (2006).

3. A.K. Beggrov, engraved Kammuller, E. K. Construction of the Admiralty embankment. World illustration10(255) 332 (1873).

4. D.A. Boitsov, The underground entrance constructructions' integration in the historical development of the biggest cities. Bulletin of Civil Engineers Publisher 1(22) 5-10 (2010).

5. R.A. Dashko, \& Y. Karpova, Underground space of Saint-Petersburg as a multicomponent system: Engineering geological and geotechnical aspects of its development SGEM 2(1), 827-833 (2015).

6. P.A. Demenkov, Predicting land-surface deformations during the construction of underground facilities of complex spatial configuration. Inter-national Journal of Civil Engineering and Technology8(11), 1161-1171 (2017).

7. P.A. Demenkov, Numerical experiments on the modeling of compensatory injection for the protection of buildings during tunneling. ARPN Journal of Engineering and Applied Sciences 23(13), 9161- 9169 (2018).

8. A.F. Eremeyeva, L.P. Lavrov, Prospective pedestrian paths in Saint-Petersburg: through neighborhoods, along the embankments. Scientific and technical journal "Bulletin of Civil Engineers"6, 5-17 (2017).

9. A.1. Gelfond, 2020. Contemporary architecture of the Baltic capitals: the global in the Identical, the Identical in the Global. International Conference on Civil, Architectural And Environmental Sciences And Technologies. IOP MSE (2019).

10. Internet source. Clarifications of property boundaries and areas by States Parties in response to the Retrospective Inventory. UNESCO decision 37 COM 8B. 54, adopted at the 37th session (Cambodia, 17-27 June 2013). Available at: (http://whc.unesco.org/en/decisions/4965. Decision: 37 COM 8D) (2013).

11. Internet source. Retrospective declaration on the outstanding universal value of the World Heritage Site "Historic Center of Saint Petersburg and Related Groups of Monuments". at:(http://kgiop.gov.spb.ru/media/uploads/userfiles/2015/08/24/Deklaratsiya_VUTs.pdf ) (2017).

12. Internet source. Available at:(https://www.cob.nl/over-ondergrondsbouwen/voorbeeldprojecten/amsterdam-amfora-amstel)(2019). 
13. Internet source. European Economic Commission. Committee for Urban Planning, Housing, and Land Use. Eighty-first Session Geneva, 6-8 October 2020 Item 8 (b) of the provisional agenda Cross-sectoral collaboration under the Economic Commission for Europe's integrated work line on Smart Sustainable Cities for All. Ages.ECE/HBP. 12, 3-5 (2020).

14. N. Kalinina, Gorod The city on the water-front or the city cut off from water? Internet source. Available at: (http://estp-blog.ru/rubrics/rid-5681) (2017).

15. V.I. Kochedamov, Embankments of the Neva River. Moscow: State publishing house of literature on construction and architecture (1954).

16. M.P. Kopkov, Harmony of the past in the present. Bulletin. Architect. The 21st century: 20-22. Saint Petersburg: "Publishing House Zodchiy" (2017).

17. V.S. Litvinenko, Advancement of geomechanics and geodynamics at the mineral ore mining and underground space development. International European Rock Mechanics Symposium, Eurock 1: 3-16 (2018).

18. J. May, Signal. Image. Architecture. Columbia Books on Architecture and the City (2019).

19. M.A. Pashkevich, Biogeochemical assessment of soils and plants in industrial, residential, and recreational areas of Saint Petersburg Journal of Mining Institute 241(1), 125-130 (2020).

20. B. Podhalański, What is metropolitan architecture? SGEM 4(1), 1145-1152 (2014).

21. A.G. Protosenya, Geomechanics of low-subsidence construction during the development of underground space in Large cities and megalopolises.Journalof Mechanical and Production Engineering Research and Development 5(9): 1005-1014 (2019).

22. M. Rafstein, Internet source. Maxim Russia. Available at:(https://www.maximonline.ru/longreads/photogallery/_article/tonnel-pod-temzoidramaticheskaya-istoriya-stroitelstva-pervogo-v-mire-tonnelya-pod-rekoi) (2020).

23. A.A. Shubin, Research of the effect of the concrete reinforcement structure on the stress-strain state of structures. International Journal of Applied Engineering Research 12(8), 1742-1751 (2017).

24. State act, Resolution of the Government of St. Petersburg dated July 23, No. 464. Land use and development rules, 8 (2019).

25. Unknown artist. Project of the granite embankment near the Winter Palace. Cut. Drawings. TSGIAL, f. 485, 1758, op. 40/211, d. 81; State Hermitage, Department of drawings. No. 16949 (1758).

26. V.R. Vuchic, Transportation for livable cities. Series: University library A. Pogorelsky: 57-62 (2011).

27. S. Zukin, Naked City: The Death and Life of Authentic Urban Places. Oxford: Oxford University Press (2009). 